\title{
Geochemistry of sediments in Johor Strait between Malaysia and Singapore
}

\begin{abstract}
We report the results of a study of the geochemistry of sediments of the Strait of Johor between the southern tip of peninsular Malaysia and the island nation of Singapore. This shallow channel in the continental shelf connects the South China Sea to the east with the Strait of Melaka to the west. We analyzed sediment layers collected at 25 locations along the east-west axis of the Strait, from the estuary of the Johor river at its eastern end to the estuary of the Pulai river at its western end, using a box corer to minimize disturbance of surficial layers.
\end{abstract}

Both trace metal concentrations and bulk sediment properties change drastically between the relatively pristine open ends of the Strait and the dam-like causeway near the east-west center of the Strait, where the greatest anthropogenic discharges occur and water flows become too sluggish to disperse them. Reasonably ñnormalò muddy sediments with oxygenated surface layers and apparently healthy benthic communities are found at both open ends of the Strait. Anoxic, watery, black muds, smelling of $\mathrm{H} 2 \mathrm{~S}$ and with no macrobenthic organisms, are found in a zone extending several kilometers on either side of the causeway built in 1924 to facilitate commerce between the island of Singapore and peninsular Malaysia. This zone of anoxic sediment has developed since the causeway was built, due primarily to discharges of sewage wastes with their high oxygen demand, and to greatly reduced water dispersion.

Total concentrations of $\mathrm{V}, \mathrm{Cr}, \mathrm{Mn}, \mathrm{Ni}, \mathrm{Cu}, \mathrm{Co}$ and possibly $\mathrm{Cd}$ and $\mathrm{Sc}$ in Johor Strait sediments are lower than concentrations estimated for average shales and mean crustal materials. This is attributed to increased solubility of all these elements during intense chemical weathering in the hot, humid tropical climate of the drainage basin. Total concentrations of $\mathrm{U}$ and $\mathrm{Th}$ are greater in Johor sediments than in both types of average materials, due to greater abundance of granites and monazites in the Johor drainage basin. Greater than global average concentrations of $\mathrm{Pb}$ and $\mathrm{Zn}$ are found in surface sediments near the causeway, due principally to additional inputs associated with large volumes of vehicular traffic across the causeway. Concentrations of As are higher in Johor sediment than in global average materials, for unknown reasons. Johor Strait sediments have rare earth concentrations less than or equal to those in average shales, and no evidence of enrichments of light rare earth elements from wastes from the large oil refineries south of Singapore Island.

Excess $210 \mathrm{~Pb}$ activities and inventories in sediments of the shallow, low latitude Johor Strait are similar to those in nearby Gulf of Thailand sediments. They are several times lower than those in sediments underlying deeper waters from mid-latitude continental shelves, due to less in situ production of $210 \mathrm{~Pb}$ from decay of parent 226Ra in the shallower Johor Strait water column, lower input of $210 \mathrm{~Pb}$ from atmospheric fallout at lower latitudes, and less riverine input of particulare $210 \mathrm{~Pb}$ to Johor Strait. Johor Strait sediment activities and inventories of this natural radionuclide are limited by its supply rather than by particulate scavenging reactions. Sediments on the tropical Amazon shelf have similar $210 \mathrm{~Pb}$ activities, 
but inventories over ten times those in Johor Strait sediments. The differences are because of much faster sediment accumulation rates on the Amazon shelf, and because lateral water transport brings more offshore waters with dissolved excess $210 \mathrm{~Pb}$ produced in situ on to the Amazon shelf than into Johor Strait.

The low excess $210 \mathrm{~Pb}$ activities in Johor Strait sediments often show erratic changes with depth that cannot be reliably modeled by assuming steady state; constant deposition rate of particles of uniform bulk chemistry, mineralogy and initial unsupported $210 \mathrm{~Pb}$ activity; and that mixing is limited to a recognizable surface layer. The $210 \mathrm{~Pb}$ profiles are still essential in explaining differences in $\mathrm{As} / \mathrm{Sc}$ and $\mathrm{Zn}, \mathrm{Pb}$, and $\mathrm{Cr}$ concentration profiles in the cores.

Keyword: Sediments; Strait; Johor; Singapore 